Creative Commons User License: CC BY-NC-ND

Abstracted by: EBSCOhost, Electronic Journals Service (EJS),

Google Scholar, Journal Seek, Scientific Commons,

Food and Agricultural Organization (FAO), CABI and Scopus

http://eoi.citefactor.org/10.11226/v24i4
Journal of Agricultural Extension

Vol. 24 (4) October, 2020

ISSN(e): 24086851; ISSN(Print); 1119944X

http://journal.aesonnigeria.org

http://www.ajol.info/index.php/iae

Email: editorinchief@aesonnigeria.org

\title{
Effects of Small Scale Irrigation on Women Farmers' Well-being Status in Sikasso Region of Mali
}

https://dx.doi.org/10.4314/jae.v24i4.13

\section{Tijani Sarafat A.}

Department of Agricultural Extension and Rural Development, Faculty of Agriculture, University of Ibadan, Ibadan, Oyo State - Nigeria. tsarafat@yahoo.com; +234-8051370802.

\section{Kone Daouda M.}

OXFAM International // Rue 124 - Porte 226, Korofina Nord-BP-209- Bamako-Mali. darounka@gmail.com; +22366199129

\section{Abstract}

This study examined effects of small scale irrigation on women farmers' wellbeing status in Sikasso Region of Mali. A multi-stage sampling procedure was used to select 160 respondents(user and non-users) while data were collected using interview schedules and analysed using percentages, mean, standard deviation and t-test. Major constraints facing users are crop damage $(\bar{x}=2.68)$, unavailability of input $(\bar{x}=2.41)$ and inadequate credit facility $(\bar{x}$ $=2.15)$. Sixty percent, $98.8 \%, 85.0 \%, 85.0 \%$ of users have higher level of material, economic, mental and social well-being, respectively compared to $25 \%, 0.0 \%, 68.8 \%$ and $35.0 \%$ of non-users with similar status. The overall wellbeing of $73.8 \%$ of users were better-off compared to $11.3 \%$ of non-users. A significant difference ( $t=11.110)$ existed in the wellbeing status of users and non-users. Utilisation of small-scale irrigation systems had positive effects on the mental, social, economic and material wellbeing of the users. There is need to extend small scale irrigation to non-users.

Keywords: Well-being, Small scale irrigation, farm size, non-users of irrigation, Mali

\section{Introduction}

Mali is a landlocked country, with dry land and desert covering $60 \%$ of the country. Mali has the largest irrigation potential in the Sahel region. It is irrigated by two large transnational river basins, the Niger and the Senegal, and also has considerable groundwater resources (Díaz-Alcaide, Martínez-Santos and Villarroya (2017), Toure, Diekkruger, Mariko and Salim (2017), Toure, Diekkruger and Mariko (2016)). It is one of the least developed countries with an economy that relies heavily on rain-fed cereal production (Zemadin, 2016). Insufficient rainfall makes agricultural production inadequate to feed the country's population, which has a growth rate of about $3 \%$ per year, with over a quarter of its population undernourished (Ministry of Agriculture and Rural Development , 2012). Mali's economy will continue to be exposed to food insecurity and climatic shocks, with limited ability to mitigate them. Economic activity was severely affected by low rainfall in 2011 and 2013 (Brouwer and Van Bodegom, 2015). A reduction in economic activity is expected to increase the number of poor 
Creative Commons User License: CC BY-NC-ND

Abstracted by: EBSCOhost, Electronic Journals Service (EJS),

Google Scholar, Journal Seek, Scientific Commons,

Food and Agricultural Organization (FAO), CABI and Scopus
Journal of Agricultural Extension

Vol. 24 (4) October, 2020

ISSN(e): 24086851; ISSN(Print); 1119944X

http://journal.aesonnigeria.org

http://www.ajol.info/index.php/jae

Email: editorinchief@aesonnigeria.org

people in the country, especially as majority of people engage in agriculture as their primary means of income.

According to Food and Agriculture Organisation of the United Nations (FAO 2016), low productivity of the agricultural sector is one of the causes of poverty in the country. Farmers in poor areas of Mali have suffered from chronic poverty and severe food insecurity being vulnerable as a result of dependency on rainfall. Rainfed agriculture is often associated with low yields and strongly influenced by weather variability. In order to make water available for farming, irrigation development, particularly small-scale irrigation is one of the major programmes embarked upon to improve agricultural production of rural farmers (women farmers especially) in Mali. Irrigation development is a main concern in order to raise production and achieve food self-sufficiency, and ensure food security for rural farmers' in particular and at the national levels at large (Ministry of Agriculture and Rural Development 2012). Irrigated farming is considered central to increasing crop productivity, enhancing food security, earning higher and more stable incomes, and increasing the prospects for multiple cropping and crop diversification (FAO, 2017). The National Strategy Irrigation Development (NSID) states that the country cannot guarantee food security for its population with rain-fed agriculture alone without a substantive contribution of irrigation. Presently, irrigation is practised on 325,430 hectares of land particularly by women farmers and concentrated mainly in the valleys of the Niger and Senegal rivers. In developing countries, women are known for making essential contributions to the agricultural and rural economies. Women are the mainstay of the agricultural sector, the farm labour force, the food systems and day-to-day family subsistence (Patil and Babus, 2018). With respect to labour for instance, Palacios-Lopez, Christiaensen and Killic (2017) noted that women constitute about $90 \%$ of the work force involved in direct arable crop production and in rearing of small ruminants in sub-Saharan region of Africa. Rural women often manage complex households and pursue multiple livelihood strategies (Vercillo, 2016). Their activities include production of agricultural crops, tending animals, processing and preparing food, working for wages in agricultural or other rural enterprises, collecting fuel and water, engaging in trade and marketing, caring for family members and maintaining their homes. Even though many of these activities are not defined as "economically active employment" in national accounts, they are however essential for the well-being of rural households.

As a result of the essential contributions of women to the agricultural and rural economies, the irrigation programme by the Malian government, which is a small scale irrigation system, targeted women farmers that are into cereal and vegetable production. These small scale irrigation systems were financed by the government while the cooperative groups formed by women farmers took over the maintenance of these irrigation systems for the sake of sustainability. Likewise, small scale irrigation systems are also owned by individual women farmers while some are provided by private organisations in Sikasso region of Mali. The programme was aimed at boosting agricultural productivity and enhancing the well-being status of farmers. It is believed that an increase in the level of production of women farmers will also translate to an increase in income, which would bring about a positive change in their well-being status. However, deficiency of simple and affordable 
Creative Commons User License: CC BY-NC-ND

Abstracted by: EBSCOhost, Electronic Journals Service (EJS), Google Scholar, Journal Seek, Scientific Commons,

Food and Agricultural Organization (FAO), CABI and Scopus
Journal of Agricultural Extension

Vol. 24 (4) October, 2020

ISSN(e): 24086851; ISSN(Print); 1119944X

http://journal.aesonnigeria.org

http://www.ajol.info/index.php/iae

Email: editorinchief@aesonnigeria.org

irrigation technology that fits the production conditions of smallholder farmers is a serious limiting factor to achieving food security and improvement of the well-being of women farmers.

Well-being is a generally description of the state of people's life situation (Pinto, Laís, Alessandra, Sílvia and José Carlos 2017). It refers to an objective or external assessment of people's daily living conditions which include their abilities and opportunities to live a good life (Buunk et al 2016). Well-being includes the presence of positive emotions and moods, satisfaction with life, fulfilment and positive functioning (Center for Disease Control and Prevention (CDCP), 2016). Well-being is a positive outcome that is meaningful for people and for many sectors of society, because it tells us that people perceive that their lives are going well.

The small scale irrigation system was developed by the Malian government with the aim of boosting agricultural productivity and enhancing the well-being status of farmers. However, the extent to which the use of small scale irrigation systems in Sikasso region of Mali has contributed to the well-being status of women farmers is not certain. The study examined effects of small scale irrigation on women farmers' well-being status in sikasso region of mali.

Specifically, the study:

ascertained types of small-scale irrigation systems used by women farmers;

identified constraints to the use of irrigation systems by women farmers; and ascertained the well-being status of women farmers.

The hypothesis was:

There is no significant difference between well-being status of users and nonusers of small scale irrigation systems.

\section{Methodology}

The study was conducted in Sikasso region (i.e southern region) of Mali, located at latitude $12^{\circ} 30^{\prime}$ North and longitude $8^{\circ} 45^{\prime}$ West (between latitude $12^{\circ} 28^{\prime}$; longitude $6^{\circ} 27^{\prime}$ and latitude $10^{\circ} 45^{\prime}$; longitude $\left.6^{\circ} 55^{\prime}\right)$. It has an area of $71,790 \mathrm{~km}^{2}$ which is $5.8 \%$ of the country's national territory. The Sikasso region has 7 circles (states) which are Bougouni, Kadiolo, Kolondieba, Koutiala, Sikasso, Yanfolila and Yorosso with 144 rural communes or local government areas (LGAs) and a population of 2,625,919 inhabitants (Ministere de l'Economie des Finances et du Budget, 2009). The hydrography of the region is made up of four important rivers (the Sankarani, the Bagoé, the Baoulé and the Banifing), permanent pools and temporary streams. In addition to rainfall, there are large areas of lowland and adaptable plains of over 140,000 ha, of which 13,029 ha are managed (Ministère de l'Agriculture du Mali, (MAM) 2010).

Multi-stage sampling procedure was adopted for this study. In the first stage, three circles (Bougouni, Kadiolo and Koutiala) out of seven circles in Sikasso region were randomly selected. Second stage involved random selection of $5 \%$ of the LGAs in each selected circle (i.e $5 \%$ of 27,9 and 36 LGAs respectively from Bougouni, Kadiolo and Koutiala) given a total of four LGAs (Koumantou LGA from Bougouni Circle; Fourou LGA from Kadiolo circle while Koningue LGA and Zangasso LGA were selected from Koutila circle). Koumantou LGA has 36villages out of which only 
Creative Commons User License: CC BY-NC-ND

Abstracted by: EBSCOhost, Electronic Journals Service (EJS), Google Scholar, Journal Seek, Scientific Commons,

Food and Agricultural Organization (FAO), CABI and Scopus
Journal of Agricultural Extension

Vol. 24 (4) October, 2020

ISSN(e): 24086851; ISSN(Print); 1119944X

http://journal.aesonnigeria.org

http://www.ajol.info/index.php/iae

Email: editorinchief@aesonnigeria.org

three have irrigation system, Fourou LGA has 23villages with three also having irrigation system, Koningue LGA has 20villages with only one has irrigation system while Zangasso LGA has 10villages with only one having irrigation system. Third stage involved purposive sampling of all the eight (8) villages with irrigation systems $(3,3,1,1$, villages respectively from kounmantou, Fourou, Koningue and Zangasso LGAs). Stage four involved randomn selection of $10 \%$ of villages without irrigation systems also constituting eight villages (3,2,2,1 villages respectively) from the same selected LGAs. In all, a total of 16villages were sampled. In stage five, ten respondents were sampled from each village thereby summing up to 160 respondentsof both users and non-users of irrigation systems. Data were obtained using a structued interview schedule. Percentages, mean, standard deviation and ttest(test of significant difference between well-being status of users and non users') were used to analyse the data. The variables of the study were measured as follows:

Type of small-scale irrigation systems used was measured on two-point scale of yes $=1$ and no $=0$. Frequency of use was later measured on a 2 -point scale of "sometimes" and "always", with scores of 1 and 2respectively assigned. The mean scores for each of the small-scale irrigation systems were obtained and used to rank them in order of use. Constraint to use of small-scale irrigation systems was measured on a 3-point scale of "not a constraint", "mild constraint" and "severe constraint", with scores of 0,1 and 2 assigned, respectively. The mean scores for each of the items were obtained and used to rank them in order of severity.

Well-being status was measured by adapting Warwick Edinburgh Mental Well-being Scale (Haver, Akerjordet, Caputi, Furunes and Magee, 2015; Gao and McLellan, 2018) of psychological wellbeing. The adapted well-being scale had four domains of well-being (i.e. material, economic, mental and social). Some of the indices used to assess the respondents' material well-being status included: the type of house they live in; ownership of the house they live in; material with which the house is built; source of drinking water and energy; means of transportation; and assets owned. Material well-being was measured on two-point scale of "yes" $=1$ and "no" $=0$. Indices of economic well-being include: ability to offer financial assistance to husband; ability to pay house rent; ability for self-reliance; and ability to meet one's daily needs. Mental well-being was measured with statements such as satisfaction with one's achievement, satisfaction with family life, satisfaction with living standard among other things. Indices used for social well-being included relationship with people, involvement or position in the community, confidence/trust in people, etc. Economic, Social and Mental well-being were measured on 3-point scale of always $=2$, sometimes $=1$ and never $=0$. Scores for each of the domains of well-being were standardised and summed, and the mean scores were also calculated. Based on the mean scores, respondents were categorised as better off/high ( $\geq$ mean 2.23, 1.94, 11.33 and 2.03 respectively for material, economic, mental and social wellbeing) and poor/low (< mean) well-being statuses. Overall well-being of respondents was calculated by summing the scores obtained in all the four domains and mean was calculated. Respondents with scores below mean $(<17.5)$ were categorised as having poor well-being status while those with mean scores and above were categorised as having better-off status. 


\section{Results and Discussion}

\section{Characteristics of Respondents}

Table 1 indicates that all the respondents belonged to at least one social group in the study area, including farmers' association and cooperatives. Farmers are often willing to join social groups if they are certain that membership of such groups will benefit them. Farmers like many entrepreneurs usually belong to association or cooperative to meet economic needs (improve income), to purchase bulk inputs at a lower price, to address market failures by increasing bargaining power on the market, to get defence against adverse socio-economic conditions, access cheap transport or storage facilities and soon. Thus, social group particularly farmers' associations and cooperatives play a major role in sustaining the livelihoods of rural communities by improving farmers' income, lending money to members and take care of farmers' welfare. Kumar, Wankhede and Gena (2015) reported that members of cooperative have immensely benefitted in increasing efficiency of various agricultural inputs and overall crop productivity, making better profit through the efforts of cooperatives. On membership of small scale irrigation users in association/cooperatives, Mhembwe \& Dube (2017) asserted that, social behaviours of local farmers have been found to be influenced by the availability of canal irrigation due to the collective water management required in irrigated societies.

Most of the respondents (40.6\%) possessed 14-25 years of farming experience, which indicates that the farmers are well experienced thus increasing the chance of them adopting improved irrigation farming technologies. Result on respondents' income shows that farmers without irrigation had lesser income compared to farmers utilising irrigation for their farming activities, which puts farmers utilising irrigation system at a better status of improved well-being compared to those not utilising irrigation system. In line with this, Mhembwe, Dube and Chiunya (2019) observed that small-scale irrigation schemes play an important role in the development of a cash economy for many rural communities and that with small-scale irrigation farming, farmers can transform themselves from a state of helplessness to improved food security through generating more income from farming. Thus, access to good irrigation facilities helps smallholders to increase their production and income. 
Creative Commons User License: CC BY-NC-ND

Abstracted by: EBSCOhost, Electronic Journals Service (EJS), Google Scholar, Journal Seek, Scientific Commons,

Food and Agricultural Organization (FAO), CABI and Scopus

http://eoi.citefactor.org/10.11226/v24i4
Journal of Agricultural Extension

Vol. 24 (4) October, 2020

ISSN(e): 24086851; ISSN(Print); 1119944X

http://journal.aesonnigeria.org

http://www.ajol.info/index.php/iae

Email: editorinchief@aesonnigeria.org

Table 1: Characteristics of respondents

\begin{tabular}{|c|c|c|c|}
\hline Variables & $\begin{array}{l}\text { Villages with } \\
\text { irrigation system } \\
(\mathrm{n}=80)\end{array}$ & $\begin{array}{l}\text { Villages without } \\
\text { irrigation system } \\
(\mathrm{n}=80)\end{array}$ & $\begin{array}{l}\text { Overall } \\
(n=160)\end{array}$ \\
\hline \multicolumn{4}{|l|}{ Social network } \\
\hline Religion group & 31.3 & 38.8 & 35.0 \\
\hline Age grade & 100.0 & 98.8 & 99.4 \\
\hline Cooperative society & 100.0 & 100.0 & 100.0 \\
\hline Women group & 100.0 & 100.0 & 100.0 \\
\hline $\begin{array}{l}\text { Town development } \\
\text { union }\end{array}$ & 83.8 & 75.0 & 79.4 \\
\hline \multicolumn{4}{|l|}{ Farming experience } \\
\hline $2-13$ & 28.8 & 18.8 & 23.8 \\
\hline $14-25$ & 40.0 & 41.3 & 40.6 \\
\hline $26-37$ & $31 . .5$ & 40.1 & 35.7 \\
\hline $\begin{array}{l}\text { Mean } \pm \text { Std. Dev. } \\
\text { Income (CFA) }\end{array}$ & $20.01 \pm 10.26$ & $24.05 \pm 10.63$ & $22.03 \pm 10.62$ \\
\hline $5000-16000$ & 43.8 & 65.0 & 54.4 \\
\hline $16001-27000$ & 35.0 & 22.5 & 28.8 \\
\hline $27001-38000$ & 13.8 & 10.0 & 11.9 \\
\hline $38001-49000$ & 6.3 & 2.5 & 1.9 \\
\hline Mean \pm Std. & & & \\
\hline
\end{tabular}

Social network ${ }^{\star *}$ multiple response

\section{Types and Frequency of Small-Scale Irrigation Systems Used by Women Farmers}

Table 2 shows the different types of small-scale irrigation systems available and utilised by the women farmers in the study area. The irrigation systems used by the women farmers are all surface irrigation, which is the irrigation method generally adopted in all countries partly due to their relatively favourable cost. Basin $(\bar{x}=2.0)$ irrigation systems was the main irrigation systems used. Under basin irrigation, water is ponded in a piece of land surrounded by earth bunds which prevent the water from flowing to adjacent fields. Since rice is one of the main crops cultivated by the women farmers, it is easy to understand why basin irrigation was commonly used by them. Basin irrigation is commonly used for growing rice on flat lands or in terraces on hillsides (Shekara et al, 2016). Shallow wells, $(\bar{x}=1.25)$, are used by farmers to tap groundwater at locations where water tables are within reach. Shallow wells provide water for supplementary irrigation. Groundwater is a reliable and accessible water source for irrigation or drinking (Chaudhary and Satheeshkumar, 2018; FAO, 2014). In flood irrigation ( $\bar{x}=0.63)$, the whole surface of the soil is covered with water. The farmer has little or no control of the water under flood irrigation, which probably is the reason why it was ranked least among the irrigation systems. Installation process in drip irrigation needs time coupled with excessive heat production and occassionally tube spoilage. The investment cost required for purchasing the 
Creative Commons User License: CC BY-NC-ND

Abstracted by: EBSCOhost, Electronic Journals Service (EJS),

Google Scholar, Journal Seek, Scientific Commons,

Food and Agricultural Organization (FAO), CABI and Scopus
Journal of Agricultural Extension

Vol. 24 (4) October, 2020

ISSN(e): 24086851; ISSN(Print); 1119944X

http://journal.aesonnigeria.org

http://www.ajol.info/index.php/jae

Email: editorinchief@aesonnigeria.org

equipment of the sprinkler irrigation system is high. Also, there is chance of water getting evaporated from the sprinkler irrigation when the surrounding environment is windy and high in terms of humidity aside requirement of continuous power supply for operating the sprinkler irrigation system. Meanwhile, Furrow irrigation is not suitable in sandy soil and for some crops particularly swap rice and vegetables that women farmers in Sikasso region of Mali were known for. The hassle involves in maintaining water flow is another challenge in furrow irrigation. All the aforementioned might accounted for non utilisation of these irrigation types among small scale irrigation users in Mali.

Table 2: Irrigation systems used

\begin{tabular}{lcl}
\hline Irrigation types & Mean & Sd. \\
\hline Basin & $2.00^{\star}$ & 0.00 \\
Shallow wells & 1.25 & 0.60 \\
Flood & 0.63 & 0.64 \\
Drip & 0.00 & 0.00 \\
Border & 0.00 & 0.00 \\
Sprinkler & 0.00 & 0.00 \\
Furrow & 0.00 & 0.00 \\
\hline
\end{tabular}

\section{- $\quad *$ Grand mean}

\section{Constraints faced by Farmers}

Results in Table 3 show that crop damage ( $\bar{x}=2.68)$, inadequate input $(\bar{x}=2.41)$ and insufficient water ( $\bar{x}=2.23$ ) were the main constraints faced by farmers utilising small scale irrigation systems. Crop damage and insufficient water could result from environmental factors such as rainfall and temperature. Pests and disease organisms also damage crops when they migrate from dry areas to irrigated farmlands where conditions are favourable for them to thrive. Dramani and Emmanuel (2020), Kaldidan (2016) and Pareek (2015) identified environmentalbased constraints as the most important factor militating against agricultural production. Access to agro-inputs is critical to improving agricultural production and food security (Hemming et al 2018). However, economic factors limit farmers' access to agro-inputs such as seeds, fertilizers and agro-chemicals. Mutambara (2016) similarly, found farmers' access to agro-inputs to be poor in Zimbabwe.

Therefore, the well-being status of the respondents may be negatively affected by these constraints. Since the 1 st and 2 nd ranked constraints are not related to irrigation water, Jovanovic et al. (2019) emphasised that providing access to irrigation water by itself is not enough, as smallholders also require a broad range of support services (Devaux et al. 2018; Diawara et al. 2018) (access to inputs, credit, and output markets) in order to achieve economic viability in small-scale irrigation schemes. Additionally, the least constraint experienced by farmers utilising small scale irrigation systems and those not utilising small scale irrigation systems was lack of marketing information ( $\bar{x}=1.21$ ), which could be as a result of poor agricultural 
Creative Commons User License: CC BY-NC-ND

Abstracted by: EBSCOhost, Electronic Journals Service (EJS),

Google Scholar, Journal Seek, Scientific Commons,

Food and Agricultural Organization (FAO), CABI and Scopus

http://eoi.citefactor.org/10.11226/v24i4
Journal of Agricultural Extension

Vol. 24 (4) October, 2020

ISSN(e): 24086851; ISSN(Print); 1119944X

http://journal.aesonnigeria.org

http://www.ajol.info/index.php/iae

Email: editorinchief@aesonnigeria.org

extension information delivery in the study area. Market for farm produce is expected to be made certain even before farmers start producing on their farm.

Table 3: Constraints faced by women farmers

\section{Constraints}

\begin{tabular}{lll} 
& Mean & Sd. \\
\hline Crop damage & $2.68^{*}$ & 0.33 \\
Inadequate input availability & 2.41 & 0.36 \\
Inadequate water & 2.23 & 0.45 \\
Inadequate credit & 2.15 & 0.48 \\
Inadequate market & 1.66 & 0.51 \\
Inadequate land & 1.63 & 0.59 \\
Inadequate access to road and & 1.59 & 0.78 \\
transport & 1.21 & 0.76 \\
Lack of marketing information & 1.21 & 0.75 \\
Competition for irrigation water among & & \\
beneficiaries of post-construction & \\
support & & \\
\hline &
\end{tabular}

\section{Well-being Status of Women Farmers}

As indicated in Figure 1,60.0\% of the respondents utilising small scale irrigation were characterised by high material (Score $\geq 2.23$ ) well-being than respondents not utilising small scale irrigation system (25\%). Impliedly, the effect of small scale irrigation systems is significant, as the material well-being of respondents utilising irrigation systems for agricultural production is better-off than those of non-users. Tijani and Ayinla (2015); Investopedia (2020) observed that material resources have the capacity of improving people's choices, comfort level, state of happiness and leisure. For instance, satisfactory accommodation is considered one of the most valuable aspects of people's lives, as unsatisfactory housing condition may have a disproportionate effect on households' material well-being (Baqutayan, Raji \&Ariffin, 2015; OECD, 2013).

Findings also show that $98.8 \%$ of the users of small scale irrigation system were characterised by high economic (score $\geq 1.94$ ) wellbeing, while all non-users $(100 \%)$ of small scale irrigation system had low economic well-being (Figure 2). This points out that respondents who use small scale irrigation system are more likely to be selfreliant than non-users, as they are more guaranteed of good yield and high income from their farming enterprises. Economic well-being can be a determinant of the level of satisfaction of individuals, to which Cheung and Lucas (2016) stated that relative difference in income has an important effect on whether individuals are satisfied or dissatisfied. Diego-Rosell, Tortora \& Bird (2018); Tijani and Ayinla (2015) also observed increase in income to be positively correlated with happiness/satisfaction 
Creative Commons User License: CC BY-NC-ND

Abstracted by: EBSCOhost, Electronic Journals Service (EJS),

Google Scholar, Journal Seek, Scientific Commons,

Food and Agricultural Organization (FAO), CABI and Scopus

http://eoi.citefactor.org/10.11226/v24i4
Journal of Agricultural Extension

Vol. 24 (4) October, 2020

ISSN(e): 24086851; ISSN(Print); 1119944X

http://journal.aesonnigeria.org

http://www.ajol.info/index.php/iae

Email: editorinchief@aesonnigeria.org

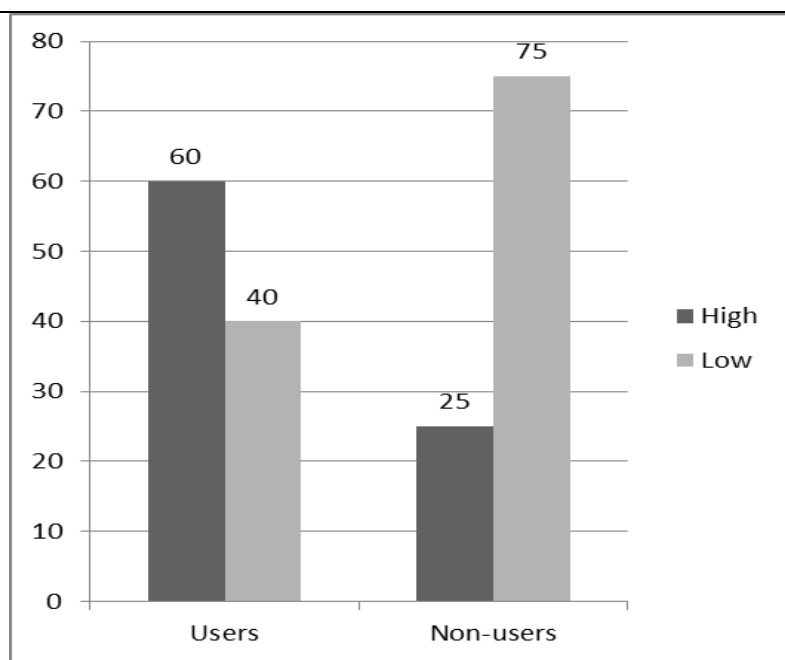

Fig. 1: Material well-being of women of women

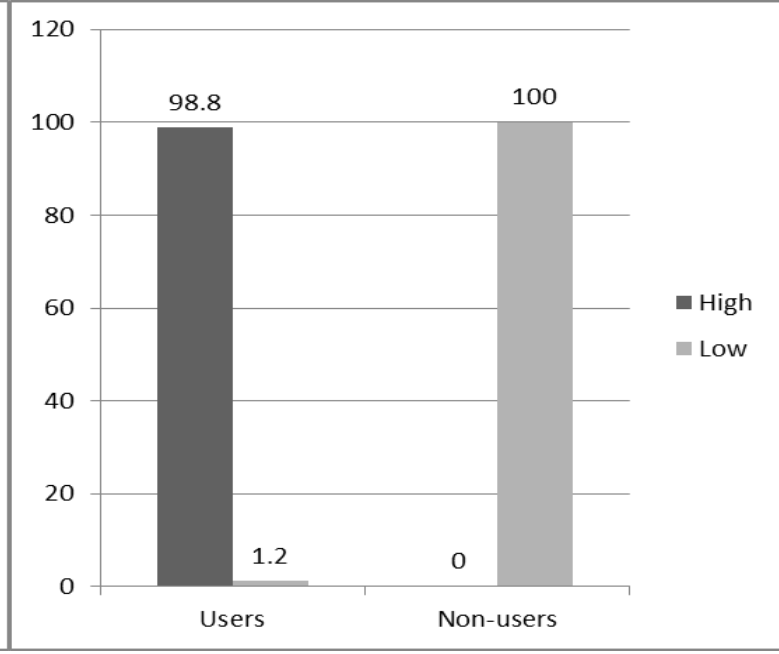

Fig.2: Economic well-being

The percentage of users of small scale irrigation system with high mental (score $\geq 11.33$ ) well-being was $85.0 \%$, relative to $68.8 \%$ of non-users (Figure 3 ). This shows that both users and non-users of small scale irrigation systems possessed high mental well-being stemming from their level of satisfaction with issues bordering on their day-to-day activities. With respect to social well-being shown in Figure 4, 52.5\% of users of small-scale irrigation system had high social (score $\geq 2.03$ ) wellbeing, which is higher than that of non-users (35.0\%). Social connection is one of the basic human needs that contribute to the fulfilment of important goals. For instance, the environment one lives in affects his or her health and ability to do a number of essential activities. When people live in an environment where they can feel secure, it can engender a good social well-being.

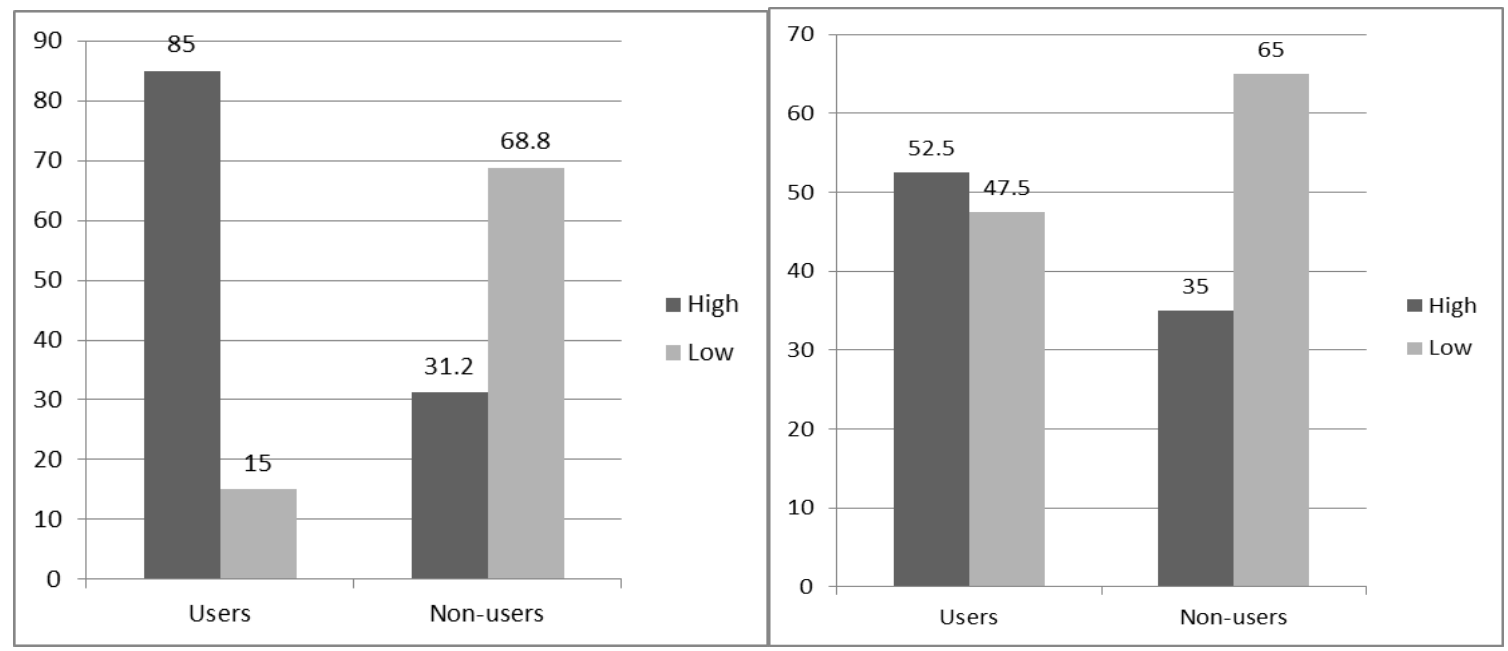

Fig. 3: Mental well-being

Fig 4: Social well-being

Figure 5 shows the overall wellbeing status of the respondents utilising irrigation system and those not utilising irrigation system. The result shows that users of irrigation system $(73.8 \%)$ were better-off (score $\geq 17.51$ ) in their wellbeing status 
than non-users of small scale irrigation system (13.8\%). This implies that the utilisation of small-scale irrigation system had a positive effect on the material, economic, mental (psychological) and social well-being of the users. It suffices to say that the use of small scale irrigation system has contributed to the improvement of their life situation. It helps to meet their economic, social material and mental responsibilities better than non users of irrigation system. Their abilities and opportunities to live a good life (Koech and Langat 2018) had been enhanced.

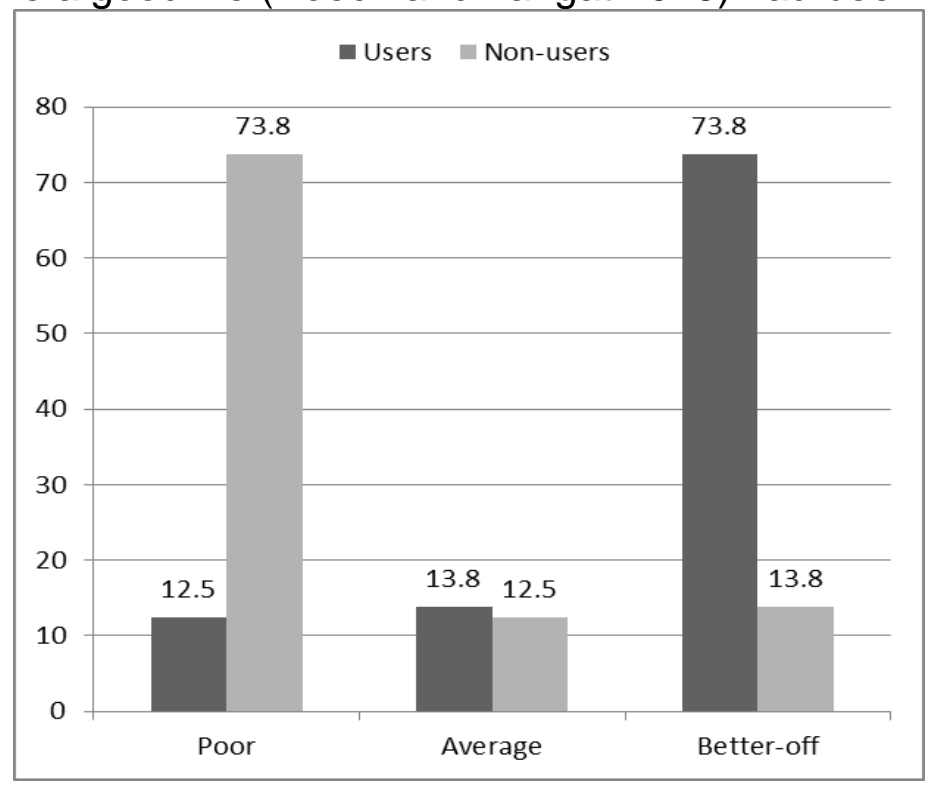

Fig. 5: Overall well-being of respondents

Result in Table 4 reveals a direct significant difference in the well-being status of users and non-users of small scale irrigation system $(t=11.110 ; p=0.000)$. This implies that the utilisation of small-scale irrigation system has contributed positively on the material, economic, mental (psychological) and social well-being of the users of small scale irrigation system. It can be inferred that small scale irrigation system has enabled users to increase the income resulting from their agricultural production and/or enhanced their livelihood activities. According to World Food Programme (2019), access to good irrigation facilities helps smallholders to increase their production and income, creates opportunities for employment, increases the opportunity for income diversification, and decreases vulnerability to drought due to short and erratic rain fall conditions. This is thus expected to translate to a better living standard and self-esteem.

\section{Conclusion and Recommendation}

Use of small-scale irrigation system was high among the women farmers, and contributed positively to their well-being status. Crops cultivated through small-scale irrigation significantly influenced the well-being status of the women. Crop damage, inadequate input and insufficient water limit the women's farm production and hence their well-being status. Provision of irrigation water alone is not enough, therefore efforts should be made to address the issue of crop damage, inadequate input and insufficient water that were limiting the use of small scale irrigation system. Such efforts will include use of crop rotation and pesticides to prevent diseases and pests 
Creative Commons User License: CC BY-NC-ND

Abstracted by: EBSCOhost, Electronic Journals Service (EJS),

Google Scholar, Journal Seek, Scientific Commons,

Food and Agricultural Organization (FAO), CABI and Scopus
Journal of Agricultural Extension

Vol. 24 (4) October, 2020

ISSN(e): 24086851; ISSN(Print); 1119944X

http://journal.aesonnigeria.org

http://www.ajol.info/index.php/jae

Email: editorinchief@aesonnigeria.org

that cause crop damage. Provision of seed and seedlings, organic (FYM, compost, leguminous plants) and inorganic fertilisers, natural (neem and pawpaw extract) or synthetic pesticides as well as extension services will go a long way to prevent and eradicate the constraints faced by the respondents. Irrigation system should be extended to other Malian women (non-users) and men in order to boost their wellbeing status.

\section{References}

Baqutayan, Shadiya Mohamed, Fauziah Raji \& Aini Suzana Ariffin (2015). The impact of housing conditions on the emotion, behaviour, and psychological wellbeing of middle-income groups. Journal of Sustainable Development, Vol. 8 (8). Canadian centre of science and education.

Brouwer, M and Van Bodegom, A.J. (2015). Climate change profile MALI, Netherlands Commission for Environmental Assessment, July 2015.

Buunk, A., Peiro, J. M., Rocabert, E., \& Dijkstra, P. (2016). Life satisfaction and status among adolescent law offenders. Criminal Behaviour and Mental Health, 26(2): 94-100.

Center for Disease Control and Prevention (CDCP) (2016). Health related quality of life. Retrieved on February 22nd, 2017 from https://www.cdc.gov/hrqol/wellbeing.htm

Chaudhary, V. and Satheeshkumar, S. (2018). Assessment of groundwater quality for drinking and irrigation purposes in arid areas of Rajasthan, India. Appl Water Sci 8(218): 1-17.

Cheung, F., \& Lucas, R. E. (2016). Income inequality is associated with stronger social comparison effects: The effect of relative income on life satisfaction. Journal of Personality and Social Psychology, 110(2): 332-341.

Devaux A, Torero M, Donovan J, Horton D. (2018). Agricultural innovation and inclusive value-chain development: a review. Journal of Agribusiness in Developing and Emerging Economies 8(1): 99-123.

Diawara B, Dicko M, Coulibaly Y, Kabirou N'Diaye M, Jamin JY, Poussin J-C. (2018). Perception by farmers of the determinants of irrigated rice yield in Mali. Agronomy for Sustainable Development 38(6): 61.

Díaz-Alcaide Silvia, Martínez-Santos Pedro and Villarroya Fermín (2017). A commune-level groundwater potential map for the Republic of Mali. Water, 9(11): 839.

Diego-Rosell, P., Tortora, R., \& Bird, J. (2018). International determinants of subjective well-being: Living in a subjectively material world. Journal of Happiness Studies, 19(1):123-143. 
Creative Commons User License: CC BY-NC-ND

Abstracted by: EBSCOhost, Electronic Journals Service (EJS),

Google Scholar, Journal Seek, Scientific Commons,

Food and Agricultural Organization (FAO), CABI and Scopus
Journal of Agricultural Extension

Vol. 24 (4) October, 2020

ISSN(e): 24086851; ISSN(Print); 1119944X

http://journal.aesonnigeria.org

http://www.ajol.info/index.php/jae

Email: editorinchief@aesonnigeria.org

Dramani J.M. File and Emmanuel Kanchebe Derbile (2020). Sunshine, temperature and wind: Community risk assessment of climate change, indigenous knowledge and climate change adaptation planning in Ghana. International Journal of Climate Change Strategies and Management, Vol. 12(1): 22-38.

Food and Agriculture Organisation of the United Nations (FAO) (2014). Irrigation techniques for small-scale farmers: Key Practices for DRR Implementers. Pp 46.

Food and Agriculture Organisation of the United Nations (FAO) (2016). Irrigation in Mali. www.fao.org/nr/water/aquastat/countries regions/mli/indexfra.stm

Food and Agriculture Organisation of the United Nations (FAO) (2017). The Future of Food and Agriculture: Trends and Challenges. Rome.

Gao, Jie. and McLellan, Ros. (2018).Using Ryff's scales of psychological well-being in adolescents in mainland China. BioMedCentral Psychology Vol. 6 (17).

Hemming, D.J., Chirwa, E.W., Ruffhead, H.J., Hill, R., Osborn, J., Langer, L., Harman, L., Coffey, C., Dorward, A. \& Phillips, D. (2018). Agricultual input subsidies for improving productivity, farm income, consumer welfare and wider growth in low- and middle income countries: A systematic review. 3ie Systematic Review 41. London: International Initiative for Impact Evaluation (3ie). Available at : http://www.3ieimpact.org/media/filer public/2018/ 06/27/sr41-agriculture-input.pdf (accessed 14 October 2018).

Haver A, Akerjordet K, Caputi P, Furunes T, Magee C. (2015). Measuring mental well-being: a validation of the Short Warwick-Edinburgh Mental Well-Being Scale in Norwegian and Swedish. Scandinavian Journal of Public Health 43:721-7.

International Water Management Institute - IWMI (2010). Irrigation in West Africa: Current Status and a View to the Future. Retrieved from http://www.iwmi.cgiar.org/

Investopedia (2020). Standard of Living vs. Quality of Life: What's the Difference? https://www.investopedia.com/articles/financial-theory/08/standard-of-livingquality-of-life.asp

Jovanovic N, Musvoto C, Clercq WD, Pienaar C, Petja B, Zairi A, Hanafi S, Ajmi T, Mailhol JC, Cheviron B, Albasha R, Habtu S, Yazew E, Kifle M, Fissahaye D, Aregay G, Habtegebreal K, Gebrekiros A, Woldu Y, Froebrich J. (2019). A comparative analysis of yield gaps and water productivity on smallholder farms in Ethiopia, South Africa and Tunisia. Irrigation and Drainage 68(S1). 
Creative Commons User License: CC BY-NC-ND

Abstracted by: EBSCOhost, Electronic Journals Service (EJS),

Google Scholar, Journal Seek, Scientific Commons,

Food and Agricultural Organization (FAO), CABI and Scopus
Journal of Agricultural Extension

Vol. 24 (4) October, 2020

ISSN(e): 24086851; ISSN(Print); 1119944X

http://journal.aesonnigeria.org

http://www.ajol.info/index.php/iae

Email: editorinchief@aesonnigeria.org

Kalkidan, F.B. (2016). The role of gender in small scale irrigation agriculture among smallholder farmers in Lume district in the central Rift valley of Ethiopia. M.S.C thesis submitted to the school of natural resources and environmental studies, Wondo Genet College of Forestry and Naturel Resources Hawasa University Wondo Genet, Ethiopia.

Koech Richard and Langat Philip (2018). Improving irrigation water use efficiency: A Review of Advances, Challenges and Opportunities in the Australian Context. Water 10 (12): 1771.

Kumar V., Wankhede K.G. \& Gena H.C, (2015). 'Role of cooperatives in improving livelihood of farmers on sustainable basis', American Journal of Educational Research 3(10): 1258-1266.

Mhembwe, S. \& Dube, E., (2017). 'The role of cooperatives in sustaining the livelihoods of rural communities: The case of rural cooperatives in Shurugwi District, Zimbabwe', Jamba Journal of Disaster Risk Studies 9(1): 1-9 https://doi.org/ 10.4102/jamba.v9i1.341

Mhembwe, S., Chiunya, N. \& Dube, E., (2019). 'The contribution of small-scale rural irrigation schemes towards food security of smallholder farmers in Zimbabwe', Jàmbá: Journal of Disaster Risk Studies 11(1), a674. https://doi.org/ 10.4102/jamba.v11i1.674

Ministry of Agriculture and Rural Development (2012). Programme National d'irrigation de Proximité (PNIP). Direction Nationale du Genie Rural. Domaine de l'Irrigation de Proximité, PASSIP/GTZ, Mali. Retrieved from http://www.developpementrural.gouv.ml.

Ministère de l'Agriculture du Mali (MAM) (2010). Programme d'Aménagement Prioritaire (PAP). Direction Nationale du Genie Rural. Domaine de l'Irrigation de Proximité, PASSIP/GTZ, Mali. Retrieved from http://www.dngr.gouv.ml/

Ministere de l'Economie des Finances et du Budget (MEFB) (2009). Recensement General de la Population et de l'Habitat du Mali (RGPHM). Institut National de la Statistique. Mars, 2013. http://www.instatmali.org/contenu/rgph/repvil09 rgph.pdf

Mumin Yazeed Abdul (2017). Small-Scale Irrigation, Farm Income and Access to Essential Services in the Busa Community of the Upper West Region of Ghana. GJDS, Vol. 14(1): 99-122

Mutambara Solomon (2016). Agricultural input supply challenges of smallholder irrigation schemes in Zimbabwe. Journal of Development and Agricultural Economics, 8(12): 260-271 
Creative Commons User License: CC BY-NC-ND

Abstracted by: EBSCOhost, Electronic Journals Service (EJS),

Google Scholar, Journal Seek, Scientific Commons,

Food and Agricultural Organization (FAO), CABI and Scopus

http://eoi.citefactor.org/10.11226/v24i4
Journal of Agricultural Extension

Vol. 24 (4) October, 2020

ISSN(e): 24086851; ISSN(Print); 1119944X

http://journal.aesonnigeria.org

http://www.aiol.info/index.php/iae

Email: editorinchief@aesonnigeria.org

Palacios-Lopez Amparo., Luc Christiaensen and Talip Kilic (2017). How much of the labor in African agriculture is provided by women? Food Policy 57: 52-63

Pareek Ashwani (2015). Influence of environmental factors on crops. J Rice Res 3:e117. doi: 10.4172/2375-4338.1000e117

Patil Basavaraj and Babus V. Suresh (2018). Role of women in agriculture. International Journal of Applied Research Vol. 4(12): 109-114

Pinto Sara, Laís Fumincelli, Alessandra Mazzo, Sílvia Caldeira, José Carlos Martins (2017). Comfort, well-being and quality of life: Discussion of the differences and similarities among the concepts. Porto Biomed. Journal 2(1): 6-12

Shekara Chandra, Kumar Ajit, Balasubramani N., Chaudhary Bakul C., Sharma Rajeev, Baumann Max (2016). Farmer's Handbook on Basic Agriculture: A Holistic Perspective of Scientific Agriculture. Second edition 154pp. Desai Fruits \& Vegetables Pvt. Ltd. Navsari, Gujarat India

Tay, L., Zyphur, M., \& Batz, C. L. (2018). Income and Subjective Well-being: Review, synthesis, and future research. In E. Diener, S. Oishi, \& L. Tay

(Eds.).Handbook of well-being Salt Lake City, UT: DEF Publishersnobascholar.com

Tijani Sarafat A. and Ayinla Maryam A. (2015). Effect of the NYSC/MDGs/WAP Agro-Enterprise loan on beneficiaries' well-being in south west Nigeria. Nigerian Journal of Rural Sociology Vol. 16 (1): $55-60$

Tijani Sarafat A. (2019). Willingness to establish private forest plantation among households in Oyo State. East African Agricultural and Forestry Journal, Vol. 83(4): 307-321

Toure Adama, Diekkrüger Bernd and Mariko Adama (2016). Impact of climate change on groundwater resources in the Klela Basin, Southern Mali. Hydrology, 3 (17):17.

Toure Adama, Diekkrüger Bernd, Mariko Adama and Cissé Abdoulaye (2017). Assessment of groundwater resources in the context of climate change and population growth: case of the Klela Basin in Southern Mali. Climate 5(3):45.

Vercillo S, (2016). 'Sustainable livelihoods and rural development', Canadian Journal of African Studies / Revue Canadienne des Études Africaines 50(2): 326-328.

World Food Programme (2019). Changing Lives for Smallholder Farmers. Beyond the Annual Performance Report 2018 Series. Rome Italy.

Zemadin B (2016). The challenges of rainfed agricultural practices in Mali-redefining 
Creative Commons User License: CC BY-NC-ND

Abstracted by: EBSCOhost, Electronic Journals Service (EJS),

Google Scholar, Journal Seek, Scientific Commons,

Food and Agricultural Organization (FAO), CABI and Scopus

http://eoi.citefactor.org/10.11226/v24i4
Journal of Agricultural Extension

Vol. 24 (4) October, 2020

ISSN(e): 24086851; ISSN(Print); 1119944X

http://journal.aesonnigeria.org

http://www.ajol.info/index.php/jae

Email: editorinchief@aesonnigeria.org

research agenda- A short communication. Adv in Plants and Agric Research, Vol. 4(1): 242-244. 